\title{
QUESTÕES DE DIREITO
}

\author{
QUESTIONS DE DROITS
}

Renan Gonçalves Rocha ${ }^{1}$

Resumo: É impossível não pensar nos direitos dos povos indígenas, quando se depara com ações estatais, econômicas e discursos que querem eliminar a existência desses povos. Ausência na demarcação de terras, destruição das políticas públicas de saúde, negligência no controle de invasão de terras indígenas (e a consequente destruição da biodiversidade) são exemplos desse cenário. Um tempo difícil, de violências variadas, índio-genocídio, políticas ambientais pífias e teses coloniais, como a do Marco Temporal. A partir desse contexto, propõe-se um esforço, um ensaio reflexivometodológico para pensar os direitos dos povos indígenas, isto é, a desestabilização da lógica jurídica para se pensar os direitos pela ótica do Outro. Talvez essa seja a maneira de abrir o Direito a Outros e, dessa forma, discutir os direitos dos povos indígenas.

PALAVRAS-CHAVE: Indígenas; Direitos; Estado.

Résumé : Il est impossible de ne pas penser aux droits des peuples autochtones du Brésil face aux actions et aux discours étatiques et économiques qui veulent empêcher l'existence de ces peuples. Il s'agit de l'absence de démarcation des terres, de la destruction des politiques de santé publique, de la négligence dans le contrôle de l'invasion des réserves autochtones (et de la destruction de la biodiversité qui en résulte). Une période difficile, de violences de toutes sortes, de génocides indiens, de politiques environnementales insuffisantes et de thèses coloniales telles que celle de Marco Temporal. C'est dans ce contexte que nous proposons un effort, un essai de réflexivométhodologique pour réfléchir sur les droits des peuples autochtones. C'est-à-dire, une déstabilisation de la logique juridique pour penser les droits du point de vue de l'Autre. C'est peutêtre la façon d'ouvrir le Droit aux Autres et de discuter ainsi des droits des peuples autochtones.

MOTS-CLES : Indigènes ; Droits ; Etat.

\section{Questões de Direito ${ }^{2}$}

\section{Perspectivas gerais e contextos.}

Neste tempo difícil, é impossível não pensar nos direitos dos povos indígenas, sobretudo quando se depara com as ações da estrutura de poder constituída com o objetivo de impedir suas existências. Vemos ausência de demarcações de terras, destruição das políticas públicas de saúde,

\footnotetext{
${ }^{1}$ Renan Gonçalves Rocha, mestre em Filosofia pela Universidade Federal de Goiás, doutorando em Filosofia pela Universidade Paris 10 e professor de Filosofia no Instituto Federal de Goiás. Email: renangrocha@yahoo.com.br .

${ }^{2}$ Agradeço a leitura prévia e revisão de Débora Ner Ribeiro e Pedro Valadares; agradeço as ponderações, sugestões e comentários de Clara Behar-Renvoise e, por fim, agradeço também os comentários, sugestões e centralmente as pistas teóricas de Janira Sodré Miranda.
} 
negligência no controle de invasão de terras indígenas (e a consequente destruição da biodiversidade) por agentes ligados a mineradoras e ao agronegócio. Não se pode esquecer também da ação de instituições religiosas e da sua lógica de homogeneização que se estabelece impondo o fim das diferenças culturais. Vivemos um tempo difícil, no qual a expressão mais direta do pensamento colonial é capaz de se exprimir sem sofisticação alguma, sem grandes aportes teóricos e, mesmo assim, ter ressonância midiática, política, jurídica.

O tempo difícil é o tempo da temporalidade simplificada e da absolutização do presente. Perfilha-se no agora, como se este exato momento, diante de nós, fosse um absoluto em si, desconectado, sem intercruzamentos com o passado e sem implicações com o futuro. Trata-se de um presente simplificado deste tempo em que vivemos. É o tempo da tese do Marco Temporal ${ }^{3}$, da produção da data pela força para questões que estão muito além da data e dessa tese de um tempo simples. Esse é apenas o sintoma da miséria deste tempo difícil e da necessidade de refletir sobre os direitos dos povos indígenas. Não obstante, cabe a pergunta: a partir de qual prisma se pode fazer essa reflexão?

Pois bem, este ensaio efetivamente tem por objetivo propor algo. Se há algum esforço reflexivo-metodológico para pensar os direitos dos povos indígenas, em primeiro lugar, deve-se sair da nossa lógica civilizacional e jurídica. Descentrar do polo único de produção do Direito segundo a lógica do pensamento ocidental dominante. O que isso significa? Dizer o que é o Direito por aquilo que ele é na sua relação com Outros. É preciso vermos pelo Outro, isto é, pela relação com Outros e pelas implicações dessa relação pela ótica do Outro. Este trabalho tenta, tensiona nesse exercício, para produzir o deslocamento necessário do retrato caricatural de Nós sobre Nós e de Nós sobre Outros. A proposta desse duplo deslocamento busca desestabilizar o narcisismo teórico sobre Nós e sobre o Direito. Trata-se de um deslocamento de nosso retrato a partir do olhar do Outro. Talvez essa seja a melhor maneira de discutir os direitos dos povos indígenas - ou, ao menos, enxergar as violências do Estado brasileiro, do seu sistema jurídico e de seus agentes sobre esses povos.

\footnotetext{
${ }^{3}$ A tese do Marco Temporal defende, grosso modo, uma interpretação de que os povos indígenas só teriam direito à demarcação das terras que estivessem sob sua posse no período da constituinte de outubro de 1988 ou que estivessem sob disputa física ou judicial naquela data. Essa tese é uma perversão histórica e conceitual, mas representativa de como economia e política são interligadas ao direito. O Marco Temporal não apenas ignora que até 1988 os povos indígenas eram tutelados pelo Estado brasileiro e impossibilitados de travar lutas judiciais, mas também legaliza a violência sobre povos que estão em disputas por terras agora, como é o caso, centralmente, do povo Guarani-Kaiowá. Tudo isso em nome dos interesses econômicos e políticos do agronegócio, das madeireiras e das mineradoras. São, em suma, determinações econômicas no direito.
} 
"Esperamos tantos anos por aquele encontro, achando que tudo se explicaria [...]. Mas a impossibilidade de nos comunicar nos colocava de novo diante de um mistério, quem são eles?" 4 .

Vincent Carelli.

Em sua descrição do massacre dos Kanoê do sul de Rondônia e de outras etnias, inclusive uma sem identificação, o indigenista e cineasta Vincent Carelli, ao conseguir seu primeiro contato, declara sua frustação e dúvida sobre quem são eles $?^{5}$. A resposta à pergunta sobre quem são esses povos era necessária para garantir a proteção de suas terras e permitir, por conseguinte, que os dispositivos legais de direito à terra pudessem funcionar. Conhecê-los seria também uma forma de saber mais sobre o massacre que sofreram e poder denunciá-lo com precisão, ou seja, encontrar os responsáveis e desnudar essa história que falava por meios de vestígios, traços, pela ausênciapresente de um massacre, que Vincent Carelli passou mais de duas décadas para poder entender.

\section{Quem são eles? Mortos em suas próprias terras - indígenas}

A pergunta quem são eles? postula a ligação entre o apagamento e extermínio de povos, que não se sabe quem são e se apaga o vivido ao impossibilitar as condições de continuidade de suas existências e de suas histórias. Quem são eles? Os povos indígenas brasileiros. Apaga-se enquanto extermina, extermina-se para apagar, num duplo movimento que não só silencia, mas também tenta destruir a voz. Esta, mesmo em silêncio, representa alguma possibilidade de dizer, de romper com o silenciamento. Silencia-se, pois há ainda vozes que dizem. As Nações indígenas brasileiras ainda têm vozes, ainda vivem e podem continuar a viver. Destacar o ainda faz sentido quando etnias inteiras deixaram de existir, fruto não somente de massacres seculares, mas também de políticas recentes de invasão de terras e da lógica de destruição dos modos de vida ou, simplesmente, da

\footnotetext{
${ }^{4}$ Carelli Vincent, Corumbiara, documentário. Produção Vídeo nas Aldeias, distribuição Vídeos nas Aldeias, 2009.

${ }^{5}$ É importante esclarecer que, nessa pergunta, o pronome pessoal eles não é um universal linguístico para designar etnias apagando as diversidades dos povos indígenas; e, sobretudo, Elas, as indígenas. Eles, assim, é utilizado por Carelli como dúvida sobre quem são essas etnias com as quais o autor se deparara. Para nós, a utilização do pronome Eles é a maneira de problematizar a dicotomização do discurso colonial. E, ao utilizar Elas, mulheres indígenas, significa escapar da universalização e, sobretudo, da essencialização do feminino, da mulher, do gênero, dentro de uma epistemologia logocêntrica que conceitua mulher e homem a partir da essencialidade. Essa é uma crítica presente na última marcha de mulheres indígenas. Essa marcha, com a presença de mulheres de mais de 130 etnias, diz em sua resolução que: “considera a necessidade do retorno $\square \square$ complementaridade entre o feminino e o masculino, sem, no entanto, conferir uma essência para o homem e para a mulher. O machismo é mais uma epidemia trazida pelos europeus. Assim, o que $\mathrm{e} \square$ considerado violência pelas mulheres não indígenas pode não ser considerado violência por nós. Isso não significa que fecharemos nossos olhos para as violências que reconhecemos que acontecem em nossas aldeias, mas sim que precisamos levar em consideração e o intuito é exatamente contrapor, problematizar e trazer reflexões críticas a respeito de práticas cotidianas e formas de organização política contemporâneas entre nós. Precisamos dialogar e fortalecer a potência das mulheres indígenas, retomando nossos valores e memórias [...]". Essa discussão está aberta, está sendo feita por elas, indígenas de diversas etnias. (http://apib.info/2019/08/15/documento-final-marcha-das-mulheresindigenas-territorio-nosso-corpo-nosso-espirito/).
} 
uniformização e da submissão de toda vida à economia do efêmero, do capital supérfluo, transnacional e hegemônico. Dentro dessa lógica, nenhuma diferença efetivamente radical é possível. É, grosso modo, mais que uma dinâmica estritamente econômica. Trata-se da subordinação a modelos hierárquicos de estruturação da vida política, social, afetiva, espiritual. etc. Tudo isso nos faz, de certo modo, crer que as etinias Xikrin, Yanomami, Terena, Guarani Kaiowá, Macuxi, Avá-Canoeiro, Xavante e outras, não são ou não estão mais aqui. Considera-se que esses povos não pertencem a esse mundo ou são incompatíveis com ele. Pensa-se que os povos indígenas não estão onde estavam e que as terras deles, constitutivas de suas existências, não são terras de direito. O argumento é simples: ‘terra demais para índio de menos'. Terra e direito: essa é nossa questão.

\section{No limite do Direito}

O direito dos povos indígenas no Brasil é uma questão que coloca o Direito no limite de si mesmo, pois somos obrigados a pensar não somente na acepção do Direito como imposição estatal, mas também na compreensão de direitos dentro e fora das estruturas legais. Isso significa um esforço criativo, para analisar o que é o Direito, sua estrutura e seu modo de funcionamento e, também, produzir aberturas de direito dentro da própria estrutura jurídica. No limiar entre o discurso soberano e a diferença radical. Quer dizer, olhar a fronteira entre Direito e Estado, entre as estruturas de poder, de discursos e poderes, que existem como formas homogeneizadoras.

Paradoxalmente, discorrer sobre direitos é imaginar uma fagulha, um resto, um vestígio de tensão, de cisão e abertura, dentro e fora do próprio Estado, do sistema jurídico, da lei. Essa noção de Direito que habita dentro e fora do Estado, como reprodução do seu poder, marca da soberania é também tensão em relação ao poder estatal. Direito que se mostra na ambivalência jurídicopolítica, social e econômica, pois dizer de direitos significa dizer da soberania e de algo que está além dela, dentro e fora do seu escopo. Isto é, dentro e além do Estado, dentro e além do Direito e da política, em choque com as forças econômicas, como questionamento que impede o esquecimento, o silêncio, o desinteresse e o menosprezo. É aí que se localizam os direitos de povos, de etnias inteiras, dos índios no Brasil. Trata-se de direitos possíveis diante da impossibilidade do sistema jurídico de reparar danos, reverter o histórico da força instituidora da própria forma Direito, Estado, Capital, e a história de formação da Nação chamada Brasil, marcada por cortes raciais e erguida pelo genocídio.

O paradoxo posto é que Direito e Estado representam, ao mesmo tempo, segurança e violência. O Estado de direito, o Brasil democrático, é metaforicamente a lâmina afiada que se 
segura e que, quanto mais se segura, mais se corta com ela. Esses cortes são, ao mesmo tempo, marcas da violência da instituição da lei e horizonte possível de interdição, o limite e controle da ferocidade do agronegócio, do capital transnacional, da compulsão de mineradoras por devorar solos (CASTRO, 2015, p. 385-386) e da violência de governos de direita, de esquerda ou simplesmente da maneira como se compreende a governabilidade no Brasil.

Insisto nesse ponto da dinâmica governamental: pois algo parece transcender as forças políticas de esquerda e de direita no que tange a essa questão. Talvez a ordem da política e o que institui o pensamento civilizacional, seus valores, conceitos e a própria epistemologia do político, estejam dentro disso que reproduz, ininterruptamente, certa marcha contra os indígenas. Ao prefaciar o livro A queda do Céu (2015) de David Kopenawa e Bruce Albert, o antropólogo Eduardo Viveiro de Castros, tece sua crítica à estrutura do governo brasileiro. Sua análise caberia facilmente à extrema direita atual. No entanto, é uma análise de governos de centro-esquerda dos últimos 16 anos. Ele diz:

No mínimo, talvez comecemos a nos dar conta de que se continuarmos a destruir obtusamente o local este local do mundo que chamamos de 'nosso' - mas quem [destaque meu] detém, para além do mero direito pronominal, o fato brutal proprietarial deste possessivo ? - não sobrarão nem fundos nem fundamentos para construirmos qualquer nacional que seja anacrônico ou futurista. [...] A queda do céu é rico em lições, entre outras, sobre a incompetência eficaz a irrelevância maligna, o ufanismo bufão da teoria e prática da governamentalidade 'nacional', esse nomos antinômico que estria e devasta simultaneamente um espaço que ele imagina instituir quando é, na verdade, literalmente suportado por ele. O Estado nacional? [...] O Brasil? [...]. Hoje ele está mais para uma corporação empresarial coberta a perder de vista por monoculturas transgênicas e agrotóxicas, crivadas de morros invertidos em buracos desconformes de onde se arrancam centenas de milhões de toneladas de minério para exportação, coberta por uma espessa nuvem de petróleo que sufoca nossas cidades enquanto trombeteamos recordes na produção de automóveis entupida por milhares de quilômetros de rios barrados para gerar uma energia de duvidosíssima 'limpeza' e ainda mais questionável destinação. [...]. Bem, a gente continua dizendo adeus - às arvores. Adeus a elas e à República, pelo menos em seu sentido original de res publica, de coisa e causa do povo. Nesse momento, nesta República, neste governo, assistimos a uma concertada maquinação política que tem como alvo as áreas de preservação ambiental, as comunidades quilombolas, as reservas extrativistas e em especial os territórios indígenas. Seu objetivo é consumar a 'liberação' (a desproteção jurídica) do máximo possível de terras públicas ou, mais geralmente, de todos aqueles espaços sob regimes tradicionais ou populares de territorialização que se mantêm fora do circuito imediato do mercado capitalista e da lógica da produtividade privada, de modo a tornar 'produtivas' essas terras, isto é, lucrativas para seus pretendentes, os grandes empresários do agronegócio, da mineração e da especulação fundiária [...]. Na verdade, são os Três Poderes da nossa República Federativa que vêm costurando uma ofensiva criminosa contra os direitos indígenas, conquistados a duras penas [...]. O presente governo [...], e me refiro aqui ao Executivo [...] vem se mostrando o de pior desempenho, desde a nossa tímida redemocratização, no tocante ao respeito a esses direitos, agravando à já péssima administração anterior sob a mesma gerência: 
procedimentos de demarcação e homologação de terras indígenas praticamente nulos; políticas de saúde mais que omissas, desastrosas para as comunidades indígenas; uma indiferença quase indistinguível da cumplicidade diante do genocídio praticado continuadamente às escâncaras sobre os Guarani-Kaiowá, ou periodicamente e "por descuido" sobre os Yanomami e outros povos nativos, bem como diante do assassinato metódico de lideranças indígenas e ambientalistas pelo país afora - quesito no qual o Brasil é como se sabe, campeão mundial". (DE CASTROS, 2015, p. 17-20)

A análise proposta por Viveiros de Castros elucida algo sobre a dinâmica de governo no Brasil. Sua reflexão nos impõe uma outra, qual seja: pensar que os direitos indígenas vão além de uma conjuntura política específica. Portanto, se podemos pensar esse tema ele deve transcender dinâmicas conjunturais e suas variações políticas. Outra temporalidade implica essa questão, um tempo além do presente e da circunstância política. Tempos antes de governos. Trata-se de um tempo outro, complexo e talvez um tempo de difícil localização. A realidade dessa temporalidade não é simples, ela é complexa e aporética. Não obstante, em tempos difíceis, a dificuldade é que o tempo aparece em um discurso simples. Dizemos isso, pois a tese do Marco Temporal, tese desse tempo difícil, simplifica toda temporalidade para distorcer direitos.

É preciso pensar direitos que atravessam governos, que é a problemática imposta quando se discute os direitos indígenas. Isso nos obriga sair da articulação simplista do tempo. É uma questão que demanda a crítica de toda a narrativa da temporalidade deste tempo difícil.

\section{O Direito e sua dinâmica}

A dinâmica do direito - ou a dupla implicação constitutiva de sua derivação soberana (DERRIDA, 1994) - consiste em que não há Direito sem soberania e sua violência. Entretanto, essa dinâmica é igualmente a possibilidade, o resíduo autocontraditório do poder do Estado para limitar o poder soberano. Se a soberania é pensada como instituição do sistema normativo, o Estado de direito se constitui no paradoxo entre produção de dispositivos, por meio da violência e de limites de sua própria violência. O Direito seria a coabitação aporética da violência e da paz, exatamente onde paz e violência não aparecem mais como antítese uma da outra, mas síntese da soberania e seus dispositivos de autolimitação. É a lâmina cortante que se segura para poder evitar a fúria do capital contra povos, e o racismo constitutivo da lógica político institucional. Em termos objetivos, isso significa, a tentativa de reduzir hostilidades da maioria sobre a minoria ou de conter uma tirania da minoria sobre a maioria (TOCQUEVILLE, 2012). Na realidade, o problema em questão não é de quantidades. Não se trata da questão de quantas pessoas constituem uma maioria ou uma minoria. Maiorias e minorias são formas exemplares de que a reprodução do poder 
ultrapassa números e lugares estanques, no instante que elas se deslocam nas representações dos imaginários de Si e dos Outros. Maiorias e minorias se reposicionam dentro da dinâmica de subalternização (SPIVAK, 1988). Por isso mesmo, os direitos dentro de dado Estado de direito significa colocar em confronto Direito e Estado, pensando Direito como derivação ambivalente do Estado e tensão, por diferentes sentidos da própria dinâmica estatal - ou tentativa de reduzir hostilidades de minorias (elites econômicas) contra maiorias. E, de maiorias (a razão normativa em si mesma, que se pensa e se pressupõe como maioria) contra minorias. A garantia dos direitos dos povos indígenas deve ultrapassar a ordem quantitativa e a ordem representativa, mas, sobretudo, deve abordar a questão do Direito e dos diversos direitos possíveis, da diversidade de direitos, dos direitos dentro e além do Estado (DERRIDA, 1997).

\title{
Tempo difícil: nesse exato momento, diante de nós.
}

Claude Lévi-Strauss explica o tempo difícil que continua, com os termos a seguir:

\begin{abstract}
Antes mesmo da chegada dos brancos, a mitologia ameríndia, dispunha de esquemas ideológicos nos quais, o lugar do invasor parecia estar reservado: dois pedaços de humanidade, oriundos da mesma criação, se juntavam, para o bem e para o mal. Essa solidariedade de origem se transforma, de modo comovente, em solidariedade de destino, na boca das vítimas mais recentes da conquista, cujo extermínio prossegue, nesse exato momento, diante de nós [destaque meu] (LÉVI-STRAUSS, 2015).
\end{abstract}

As palavras de Strauss sobre os povos indígenas no Brasil são importantes, pois mostram o esforço do antropólogo em denunciar o extermínio de povos reféns da violência supérflua. Violência em curso. Grave questão desse tempo difícil: o índio-genocídio continua. Entretanto, outras questões surgem ao lermos as palavras de Strauss. Uma delas é a classificação desses povos como os povos ameríndios, com suas belas e complexas mitologias. Essa classificação é em si a continuidade institucional do contato colonial. O extermínio não pode parar e não produz empatia, porque Eles serão sempre os povos ameríndios, os índios, os outros que nós pensamos e discutimos com nossos textos e reflexões. Se discutimos, pensamos, falamos sobre Eles, primeiro e, antes de tudo, já usamos a língua dominante e nossa compreensão do problema. Mas, indígenas são efetivamente um problema? Para analisá-los, pensa-se na ciência. Crê-se na isenção analítica, na suposta neutralidade da atividade científica. Usa-se o sistema jurídico e sua linguagem, pois trata-se de uma questão de direitos. Mas, primordialmente é uma questão de língua e linguagem, da soberania como língua dominante e imposição dos pressupostos da reflexão. Direito, língua e linguagem são junções fluidas do poder e elementos indispensáveis para a constituição do Brasil como forma estatal, nacional e da dominação etino-genocida que se produz a partir dessa forma Brasil - latinaamericana-lusófona - da República e do Estado de direito. 
A dificuldade da denúncia de Strauss é que, nesse caso, a denúncia classifica, e, essa classificação é feita em termos inevitavelmente coloniais. A denúncia da violência porta a contradição de permanecer dentro disso que se enseja modificar. Quando se expõe, aqui mesmo neste texto, sobre direitos dos povos indigenas, estamos com Strauss na contradição de falar de direitos por um lado, e, por outro, de reproduzir a instituição da distância entre Eles (etnias inteiras) e Nós. Se fala de direitos dos povos indígenas, pois esses Outros não somos Nós. Ao contrário, são Outros que morrem sob nossas vistas. Strauss pensa a partir da separação radical entre Eles e Nós, como se houvesse um extermínio que, sem nos implicar, pudéssemos apenas vê-lo, como uma cena trágica que se passa diante de nós.

No entanto cabe interpelar a reflexão de Strauss, não somente no sentido da denúncia ao extermínio que se passa em nossa frente, mas de questionar o Nós do diante de... Pois, devemos nos perguntar: esse Nós, essa separação radical, não seria, principalmente, uma invenção política, jurídica, linguística, forjada pelo apagamento e anulação da diferença? Contudo, na medida em que, se pode estabelecer o Nós, ou dizer de Nós, isso é possível apenas na relação com Outro. Assim, não há Nós em si, nem uma unidade homogênea nesse suposto Nós. O Nós que menciona Strauss não é, dessa forma, uma identidade idêntica. Ao contrário, se existe Nós ele é constituído de conflitos, de diferenças radicais e do encontro inevitável com Outro, isto é, da impossibilidade de dizer Nós sem Outros. A construção do Nós seria, nesse aspecto, principalmente a tomada de posição para delimitar o Outro, para distinção de outros num pensamento hierarquizante. Eles são, dessa maneira, esses Outros que estão longes de Nós e são estranhos a Nós. Não são pensados como constitutivos de e do Nós. São analisados por nós (e aí está uma das hierarquias do discurso analítico), como culturas, modos de vidas, costumes e pensamentos que não são o nosso. No prisma dessa visão dicotômica e da separação entre Nós e Eles, os povos indígenas serão, dessa maneira, vistos como os ameríndios, os índios, classificados a partir da categoria genérica de designação do Outro. Os ameríndios, contudo, não se veem como ameríndios mas dentro de suas diversidades étnicas. Contudo, foram obrigados a nos ver como $b_{\text {ancos }}{ }^{6}$. Isso caracteriza uma maneira de compreender quem são esses Outros que desencadearam e se construíram à partir da relação antagônica com Eles. Um duplo movimento de compreensão do Outro, pois, se há algum esforço metodológico a ser feito para pensar os direitos dos povos indígenas, ele passa primeiro por ver essa lógica do Outro, ou o outro do Outro, como maneira de vermos a nós mesmos e talvez isso que são os direitos do Outro.

\footnotetext{
${ }^{6}$ A noção Branco, apenas para introduzir essa vasta discussão, é, por exemplo, em Yanomami, napë - termo que define a condição de uma relação mutável, isto é, os Brancos são "os membros (de qualquer cor) daquelas sociedades nacionais que destruíram a autonomia política e a suficiência econômica do povo nativo de referência”. (DE CASTROS, 2015, p.12).
} 
É preciso nos vermos pelo Outro, isto é, pela relação com Outros e as implicações dessa relação pela ótica do Outro, onde Nós somos o desenho do Outro sobre Nós. Esse é o exercício possível para produzir o deslocamento necessário do retrato caricatural de Nós sobre Nós e de Nós sobre Outros. De certa forma esse duplo deslocamento desestabiliza o narcisismo do Nós. Olhar de Nós sobre nosso próprio retrato. Ver nosso retrato sobre o olhar do Outro é, por assim dizer, a melhor maneira de discutir os direitos dos povos indígenas. É a maneira de ver os massacres produzidos pelo Estado brasileiro e seus agentes ${ }^{7}$. E, igualmente, notar a dissimetria hierárquica e o estabelecimento da dicotomia entre Nós e Eles. A dimensão uniformizadora dos dispositivos subjetivos, as heranças, os fantasmas da colonialidade. É a partir do retrato do Outro sobre Nós, os Outros de Outros que talvez podemos fazer a crítica do que se passa diante de nós. Crítica à herança colonial e a sua continuidade espectral, marcas fortes deste tempo difícil.

Nesse contexto, discutir os direitos dos povos indígenas significa ver nosso retrato ou o retrato do Estado e do Direito em uma perspectiva antinarcísica ${ }^{8}$. Ou seja, à partir da fratura da visão de si e da busca do Outro como crítica do Nós. Significa vermos o que é o Estado de direito

\footnotetext{
7 Ver Relatório Figueiredo. 2013. Disponível em: http://www.mpf.mp.br/atuacao-tematica/ccr6/dados-daatuacao/grupos-de-trabalho/violacao-dos-direitos-dos-povos-indigenas-e-registro-militar/relatorio-figueiredo. Sobre esse relatório me detenho, nesse texto, apenas a citar 1) As palavras do Ministério Público Federal que resumem as mais de 7 mil páginas nos termos seguintes: "Depois de 45 anos desaparecido, o Relatório Figueiredo, que apurou matanças de comunidades inteiras, torturas e toda sorte de crueldades praticadas contra indígenas em todo o país principalmente por latifundiários e funcionários do extinto Serviço de Proteção ao Índio (SPI) —, ressurgiu quase intacto em abril de 2013. Supostamente eliminado em um incêndio no Ministério da Agricultura, ele foi encontrado no Museu do Índio, no Rio de Janeiro, com mais de 7 mil páginas preservadas e contendo 29 dos 30 tomos originais. Entre denúncias de caçadas humanas promovidas com metralhadoras e dinamites atiradas de aviões, inoculações propositais de varíola em povoados isolados e doações de açúcar misturado a estricnina - um veneno. [...] o texto, redigido pelo então procurador Jader de Figueiredo Correia [...] apura violações de direitos humanos cometidas entre 1946 e 1988. A investigação, feita em plena ditadura, a pedido do então ministro do Interior, Albuquerque Lima, em 1967, foi o resultado de uma expedição que percorreu mais de 16 mil quilômetros, entrevistou dezenas de agentes do SPI e visitou mais de 130 postos indígenas. Órgão criado em 1910, quando várias frentes de expansão avançavam para o interior do país, o SPI era ligado ao Ministério do Interior e funcionou até 1967, quando foi substituído pela Fundação Nacional do Índio (Funai). Os únicos registros do relatório disponíveis até então eram os presentes em reportagens publicadas na época de sua conclusão, quando houve uma entrevista coletiva no Ministério do Interior, em março de 1968, para detalhar o que fora constatado por Jader e sua equipe". E, cito também um excerto do texto do relator: "o índio, tornou-se vítima de verdadeiro celerado, que lhe impuseram um regime de escravidão e lhe negaram o mínimo de condição de vida, compatível com a dignidade da pessoa humana". Relatório Figueiredo, 2013.

8 Viveiros de Castros utiliza essa noção para pensar a Antropologia: "se Édipo é visto como protagonista da psicanálise, eu costumo provocar meus colegas de profissão dizendo que o nosso é Narciso. Nossa profissão parece obcecada em saber o que distingue "nós" dos outros. O que torna "nós", os homens, tão especiais diante do resto da criação? Ou o que diferencia "nós", os ocidentais, ou "nós", os sujeitos dos discursos antropológicos, daquelas outras sociedades que não fazem Antropologia? Não esqueçamos que Antropologia é o estudo do homem, mas, ao mesmo tempo, do homem mais diferente possível daquele que enuncia o discurso da Antropologia o selvagem, o primitivo. [...] Nós, os ocidentais? Nós, os brasileiros? Nós, os homens, em oposição às mulheres? Ou nós, os humanos, em oposição aos não humanos? $\mathrm{Na}$ verdade, a Antropologia é uma discussão de quem somos nós. Mas não de qual é a nossa essência do humano, e sim quem diz "nós" em que condições. Não sei até que ponto isso é tão diferente da psicanálise. [...] Todas essas ausências são muito semelhantes. Parece que o problema é que a própria questão - "O que nos torna diferentes dos outros?"- já contém em si a resposta: de um lado nós e, do outro, eles - os outros, que podem ser vários outros, pouco importa, porque o que nos interessa na verdade somos nós. É aí que há o narcisismo e o antinarcisismo constantes. O sujeito do discurso antropológico: perguntar o que nos faz diferente dos outros já é uma resposta, porque o que importa não são eles, e sim nós". (DE CASTROS, 2010, 15-26).
} 
no Brasil e o que são os direitos dos povos indígenas, pela ótica do Outro e não pela Teoria do Direito, ou pela Filosofia Crítica, ou pelas formulações das teorias filosófico-políticas dos direitos humanos. Mas sim por aquilo que o Direito não pode ver nem dizer de si mesmo. Instante no qual pode-se pensar o encontro com outro Direito, um direito fora de si, fora de sua filosofia e de suas intenções. Gesto antinarcísico que questiona as teorias do direito e problematiza isso que elas dizem sobre o que são e o que podem ser os direitos. Problematizar dessa forma o Direito não é estabelecer o que nós pensamos sobre o que ele é, mas, o que ele se torna nesse contato com o Outro. No limite onde nenhuma Teoria do Direito seria possível sem Outros. É aí que encontramos um outro Direito, e outros direitos, fora de sua intencionalidade, fora de sua visão narcísica.

Nesse sentido, discutir os direitos dos povos indígenas significa levar primeiro em consideração esse duplo movimento de constituição do Outro e nos demandarmos quem é o Outro e quem é o Outro do Outro. Trata-se de um exercício de esvaziamento do Outro, do fetiche sobre o Outro. Trata-se igualmente de abrir a possibilidade de pensarmos a história, a política, a vida social constituída e chegarmos à imagem das instituições brasileiras, da cultura no Brasil, da língua que falamos, por uma via que não seja essa da nossa própria reprodução do lago espelhado de Narciso. Instante anti-egóico da imagem de Si e abertura para Outro como questionamento da beleza críticocivilizacional e progressista. Questionamento do narcisismo econômico do capital e da inclusão dos povos indígenas no mundo da mercadoria, do agronegócio.

\section{$* * *$}

Quando Strauss expõe que o extermínio dos povos indígenas prossegue, "nesse exato momento", ele articula a junção temporal que identifica a continuidade do passado no presente. A atualidade é, portanto, um desafio além do presente, uma vez que o presente é antes implicado em elementos que ultrapassam a presença do presente. O tempo presente existe na medida em que ele não está isolado do que se viveu no passado. Ele prossegue, como repetição, entrecruzando igualmente com o futuro. O extermínio prossegue diz Strauss. Isso mostra a articulação entre passado e presente numa cadeia repetitiva, que envolve toda temporalidade. Ou seja, o futuro também não escapa dessa estrutura. Com Strauss, nota-se assim a complexificação do discurso sobre o tempo. Pode-se pensar também que o tempo traz questões e exigências de respostas. Deve-se refletir se a responsabilidade pode ser pensada como a resposta a uma questão. A resposta responsável a essa questão dos direitos indígenas atravessa no mínimo uma temporalidade complexa. Por conseguinte, a articulação sugerida por Strauss do passado no presente, ou a herança do extermínio que continua, suscita uma noção de responsabilidade além do presente; do agora; deste exato momento, diante de nós.

Ao articular passado, presente e futuro, por meio da noção de continuidade, Strauss diz que 
o presente não pode ser pensado em si mesmo, sem passado ou futuro. Ora, o extermínio continua diz Strauss. Uma questão determinada no presente. Mas, essa questão não pode ser pensada sem se pensar o passado. A problemática é então dar resposta ao exterminio em toda sua temporalidade. A resposta ao que se passa neste exato momento significa, ao menos, refletir com o passado e sua complexificação do presente. Em outras palavras, significa repensar os limites temporais da responsabilidade ou da simplificação do tempo pela data. Esse aspecto controverso do tempo nos faz interrogar que o tempo da responsabilidade não é exclusivamente o presente. Portanto, uma resposta responsável no presente desestabiliza o tempo como presente em si.

\section{Direito à terra direito à vida.}

O termo utilizado por Strauss, notemos bem, é exterminio. Por conseguinte, é a questão da vida que está no âmago da sua reflexão. É também o ponto de partida para se pensar uma questão de direito. $\mathrm{Na}$ verdade, uma questão de direito e de responsabilidade, que rompe com a temporalidade presente e sua presença, como o tempo simples deste tempo difícil.

Se pensar o direito obriga imediatamente pensar a questão do direito à vida, nesse caso, sobretudo agora, torna-se inseparável pensar a questão do direito à terra como direito à vida. Não há direito sem pressuposição à vida, e terra para os povos indígenas é vida. Pensar terra e indígenas de forma radicalmente dissociadas nos remete à história da violência do discurso sobre as etnias e suas relações com a terra. Muito além de uma cosmologia que pensa a terra como uma sacralidade exterior a si, dentro de diversas tradições, como os Yanomami (KOPENAWA, 2015) por exemplo, a terra é parte de si mesmo, e não uma forma de pensamento de um outro como exterioridade. Terra é o si mesmo, a vida mesma, algo necessário ao modo de vida e subsistência, elemento constitutivo de suas ontologias. Ela é suas espiritualidades, no limite onde não é possível vida indígena sem terra. Essa complexidade demarca diferenças. Pois o direito à terra é sinônimo de direito à vida. Dessa forma, toda tentativa de disjunção entre terra e vida se traduzirá em etnocídio e destruição gradativa de povos. Essa separação forçada de conceitos, disjunção caricatural da história do conceito de índio, impossibilita seus modos de vidas interligados à terra e a vida mesma desses povos.

\section{O Outro}

A conceituação dos povos indígenas como Outro a partir das referências universais, tem como repercussão prática, políticas públicas derivadas de representações etnocidas, inclusivas e, portanto, autoritárias. No final, as discussões assimilacionistas e integracionistas são formas de inclusão. De fato, nem todo discurso pela inclusão social representa algo efetivamente democrático. Nesse caso, ao contrário, eles representam a razão dominante na sua pulsão de apagamento das 
diferenças e aniquilição mesma da outridade, pela diluição identitária ${ }^{9}$. O pensamento do Outro a partir dos universais expõe o embaraço da generosidade humanitária, que vislumbra a inclusão social, ou seja, a inclusão no nosso social, nesse social epistêmico-sociológico-moderno, que determina o comum, o nós e o eles dentro da hierarquia de Nós sobre Eles. Olhar egóico no qual a autocentralização do Eu não abre e não permite sentidos para Outros fora do Eu-Mesmo. Trata-se, grosso modo, de inclusão no Eu de tudo que não seja Eu-Mesmo, de exterminação dos Outros que não podem estar no Eu.

\section{Inflexão.}

O ponto de inflexão que se deve pensar e amadurecer não passa por uma questão de inclusão nem de exclusão e de isolamentos impossíveis deles, os povos indígenas, mas de transbordamento da tipologia e da topologia dicotômica do dentro-fora. Isso ocorre em um gesto de constranger e alargar o Direito, momento no qual os direitos excedem o Direito e se constituem na ambivalência de direitos dentro e fora do Direito. Em outras palavras, o Direito é tomado como pressuposto, a partir do qual algo pode lhe escapar, no limite onde o dentro do Direito já se constitui como uma realidade social, cultural, econômica, legislativa e de vidas exteriores e interiores a ele ${ }^{10}$. Dessa forma, falar sobre direitos deve implicar desmonte e deslocamento do próprio Direito, do seu significado, da sua tipologia, da sua instrumentalidade e da sua normatividade. Expandindo o campo de atração imediato entre o Direito e poder do Estado como soberano sobre o direito natural à vida dos povos indígenas.

\section{Indígenas e Nós}

A dissociação forçada entre terra e indígenas é, finalmente, a disjunção entre povos e suas vidas, portanto anulação de todo direito. No entanto, uma distinção deve ser feita, pois, diferente do direito à terra como direito a propriedade ou a posse, o direito à terra para os povos indígenas se articula na diferença e no choque com essas noções. Os termos e as lógicas são outras. Cabe refletirmos sobre essa diferença. Diferença deles, e não nossa.

De modo ambivalente, a distinção institucional entre Nós e os povos indígenas, ameríndios, abre a dupla ligação para podermos, nessa distinção, falar sobre direitos diferentes. Tal distinção

\footnotetext{
${ }^{9}$ Agradeço Janira Sodré por sugerir a noção de diluição identitária.

${ }^{10}$ Assim, por exemplo, para os Macuxi, esclarece Janira Sodré Miranda, "o discurso político adquire uma conotação de diálogo com o exterior, com a chamada sociedade envolvente, ou ainda com a parentela, sempre com o objetivo de problematizar [sua própria situação política]. Fica estabelecido então outro foro de legitimidade [...]. (SODRÉ, 2018, p. 127-145)
} 
porta, ao mesmo tempo, a violência da determinação colonial e uma marca da diferença radical, isto é, a diferença entre Eles povos indígenas e Nós não-índios, que nos permite refletir sobre as diferenças no interior da própria violência. Eles, esses Outros, têm outras relações com a terra, que não são as mesmas que a nossa. Pensá-los como Eles diferentes de Nós é também algo que nos permite arrazoar a diferença de compreensão do significado de terra, muito além do conceito de propriedade. Diferença entre Eles e Nós.

Nesse sentido para se discutir a questão dos direitos dos povos indígenas deve-se partir da cisão mesma entre Nós e Eles, pois, dessa forma, podemos levar em conta a relação entre indígenas e Direito. Para tanto é preciso descortinar essa relação, momento que Direito e Estado são pensados pelas diversidades étnicas, e não pela tecnocracia jurídica. Então são Eles, e não Nós, que devem poder dizer o que é o Direito e quais são seus direitos. E, além disso, são Eles, e não Nós, que podem determinar o que é o Direito na sua relação com Eles. É a forma de deslocamento da própria lógica do Direito e sua teoria autodescritiva.

\section{Marco temporal - ou a herança colonial}

Se Strauss pensa o intercruzamento temporal, ou seja, o passado imbricado no presente como junção em um tempo da continuidade, é para expor a complexidade da temporalidade da questão dos direitos indígenas. A simplificação do tempo, ou a datação, são, assim, instrumentos insuficientes para pensar o tempo da continuidade como ligação entre pretérito, presente e futuro. Por isso a atualidade é um desafio além do tempo presente. $\mathrm{O}$ atual existe como prosseguimento do passado que está no presente. Estabelecer direitos agora, hoje, atualmente, não pode ser, a partir da datação do agora. Isso seria no mínimo irresponsável, pois é a desconsideração de problemas que ultrapassam a presença do presente, que excedem a data. Esse é um dos problemas imanentes no discurso do Marco Temporal.

Dessa forma devemos nos perguntar: o Marco Temporal não seria, no fim das contas, uma questão de direitos dentro e além do Direito? Esse debate não parece dizer algo também sobre a pergunta quem? Ou melhor, quem são eles? Ou ainda, esses povos estão ou estavam aqui nessas terras? Os povos indígenas precisão mesmo delas? Todo esse debate é sintoma de uma política, mais larga que governos, e de relações sociais pautadas por processos socioeconômicos e culturais absolutamente diferentes dos modos de vida indígenas. Pensemos no caso dos Kanoê que evocamos no início deste texto. 


\title{
Kanoê de Corumbiara em choque com o Marco temporal.
}

\author{
"A questão não é mais provar ou não provar, é contar a história" \\ "O índio só passará a existir legalmente se conseguirmos uma imagem \\ dele". \\ "Índio que ninguém viu é boato".
}

\section{Vincent Carelli ${ }^{11}$.}

O desconhecimento profundo de um país inteiro sobre quem são os povos indígenas, demarca claramente como a indiferença não indígena aos indígenas pode ser aceita enquanto modo de ação e poder, e de fato é o seu modelo de funcionamento. Mais que a ausência de acesso a dados, estatísticas e perspectivas antropológicas, criam-se imaginários da inexistência para se justificar a indiferença. Esse é o caso relatado por Vincent Carelli em Corumbiara.

Carelli mostra que, apesar de todos vestígios de que havia índios isolados em terras prontas a serem apropriadas por uma empresa agrícola. E, do fato de agentes públicos (da FUNAI) os terem visto. A existência jurídica desses povos só foi reconhecida quando virou uma imagem cinematográfica. A produção do imaginário do inexistente é isso: se diz, se relata que havia povos indígenas em terras brasileiras, sabe-se que existem vários sem contato (intensivo ao menos), mas, ainda sim, diante dos vestígios, dos rastros que comprovam suas vidas (por mais fortes e evidentes que sejam), há suspeitas, há descrença jurídico-formal de que Eles de fato existem.

\section{A exigência da prova.}

O imaginário do inexistente insiste na dúvida. Insiste em uma suposta busca pela "verdade mesma", "por provas contundentes e indubitáveis". No caso das etnias de Corumbiara, somente diante da aparição cinematográfica - em grande rede de televisão nacional - teve-se alguma iniciativa do poder público e, de certa forma, algum reconhecimento de direitos. A imagem é o que dá materialidade jurídica a vida. É como se um povo não pudesse ser anterior a sua aparição e a imagem fosse elevada a um limite muito além da imagem. Limite que atribui um senso de valor a ela que vale muito mais que mil palavras e muito mais que vestígios e provas. É como se a imagem valesse mais do que um povo ou o que sobrou dele. De fato, o espetáculo da imagem permitiu que esses índios passassem a ter algum direito. Ou melhor, as etnias indígenas de Corumbiara não passaram a ser protegidas por uma questão de vida em si mesma ou pelo simples fato de que o menor vestígio de vida seria, precedente a qualquer prova, suficiente para se querer, se dever, se

${ }^{11}$ Corumbiara, op.cit. 
tentar preservar suas vidas. $\mathrm{Na}$ realidade, nesse caso, suas vidas valiam tanto quanto o espetáculo da imagem. São vidas jurídicas, depois da imagem, isto é, uma forma de pensar direitos fora de toda e qualquer lógica constitucional.

O problema posto é que, apesar de todas as evidências e da materialidade da existência desses povos, isolados ou não, e por mais que se comprovasse que eles existiam a dúvida sobre suas vidas pôde ser levantada de múltiplas formas. Isso quer dizer que essas etnias só existiram diante da prova espetacular. De todo modo, são provas sempre em dúvida. São existências a partir dos exames e das provas, não são, portanto, anteriores à prova, ao saber, à resposta à pergunta Quem são eles?

É uma busca impossível pela prova mesma. Essa busca é impossível, pois sempre se pode criar elementos para se duvidar da verdade do material experimentado. É um exercício sem fim de contestação da prova pela ciência. Aqui, porém, não é uma questão de prova científica, e sim de poder e de direito. Poder de validar uma prova, de determinar o que é a verdade da prova e do direito de existir antes de qualquer discussão jurídica, anteriormente ao Estado, a Nação, antes do Brasil e de sua colonização.

O fato é que, antecedendo à prova, temos um problema de pressuposto. Instaurou-se, nessa situação, a pressuposição da prova antes dos índios. Um problema que leva à reificação absoluta dos indígenas, uma vez que, para se certificar de suas existências, Eles passaram a ser um objeto da ciência e do Direito. O Direito reconhece-os a partir da ciência. São povos e culturas, modos de vida e pessoas que não existem anteriormente à sua regulamentação. E, se regulamenta somente depois das provas. Não são para o Direito antes das provas e não são para ciência antes dos exames. Não são, não podem ser, uma inquietação anterior à prova, aos exames, para essa dinâmica da indiferença. Contudo, a indiferença do Estado existe dentro da ambivalência, isto é, dentro de uma diferenciação sistemática. Se é indiferente, é indiferente a quem? Nesse caso, temos indiferença às vidas indígenas. Trata-se da diferenciação hierárquica que movimenta o próprio posicionamento indiferente. Assim, para que esses povos indígenas pudessem existir dentro do Estado de direito, como disse Vincent Carelli, precisou-se de uma imagem deles. Somente dessa maneira Eles foram validados diante da lei.

Nesse caso, a imagem foi garantia de que esses povos não seriam mortos. Para garantir suas vidas, somente uma filmagem, uma foto, uma prova convincente, válida, poderia fazer com que a indiferença de Estado se tornasse direito. O poder pautado por uma ação indiferente produz assim 
anomalias segundo a qual uma foto ou uma filmagem é tão valiosa quanto suas vidas. Essa visão produz também uma distorção, na qual a vida não é uma preocupação que antecede qualquer prova.

As etnias de Corumbiara poderiam ser eliminadas, não por decisão de um burocrata pautado pela ideia de cumprir uma ordem banalmente, nem mesmo por uma decisão radical do Estado, mas pela superindiferença conexa à lógica de poder em questão. Lógica essa que, apesar de ser movimentada pela banalidade, está ancorada em interesses conjunturais e radicais: forças econômicas vorazes e relações sociais que uniformizam destruindo diferenças enquanto subjugam o Outro.

O problema da prova, da prova mesma que se remete à ideia da verdade mesma, das verdades metafísicas, esse é um problema indissolúvel. Cabe perguntar, qual é a verdade aí estabelecida? Qual é a verdade da prova? Anterior a prova, contudo, vêm os pressupostos de como se infere a comprovação. Como se prova o que se quer provar? Quais pressupostos? Quem prova? Quem pressupõe provar? Quem pressupõe duvidar? Qual dúvida? Quem duvida? Quais os pressupostos da dúvida? Essas questões nos levam centralmente à base jurídica de constituição da prova. Não há prova enquanto ela não seja validada pelo direito. Isso, em síntese, significa que a chamada "questão indígena" não é uma questão de prova em si, da verdade, mas, antes, é uma questão de direito. De direito e poder, do poder do Direito, que diz o que é válido como prova. É também uma questão dentro e além do Direito. É uma questão de apagamento de um direito que existe porque apaga. Direito que se institui arbitrariamente, sem contrato, sem natureza, sem divindade, se constitui pela violência, se funda sem fundamento, se perpetua pelo apagamento, pela violência contra povos.

Essa é a marca da soberania, da grande violência que é a ação de soberania. Uma soberania que determina o começo, que diz o que começa e determina o tempo como um ato de poder soberano. Em outras palavras, a temporalidade, o posterior e o anterior não são em si mesmos, não poderiam ser. São, não obstante, violência soberana, determinados e marcados por ela. Dizer que não há índio antes da prova, para os índios, significa dizer que eles são delimitados pelo direito como manifestação da soberania. Essa é uma violência do Direito, do poder do Estado soberano, desse Estado que evoca uma constituição que regulamenta o tempo: passado, presente e futuro. Estado que, soberano, pode deixar viver ou fazer morrer. O Marco Temporal, no final, não marca o tempo de uma questão de direitos, mas é simplesmente a imposição arbitrária de um tempo sem ressonância com os direitos indígenas. Cujos efeitos são a distopia entre o Direito e a Morte. 


\section{Para não finalizar e abrir...}

Para continuarem existindo, os povos indígenas são obrigados a entrar em uma linguagem completamente nova - tanto outra linguagem da nova língua, o português, como, sobretudo hoje, a estranha linguagem do Direito e da política. Os povos indígenas não são a maioria, nem a minoria. Estão dentro, mas também fora dessas lógicas políticas democráticas, que os empurram cada vez mais para fora, mas que não os deixam sair completamente. Aqui a democracia também é um problema. Ela é, primordialmente, uma violência.

Os povos indígenas estavam aqui nessas terras antes de todo e qualquer Direito, e sob o seu próprio direito. Esse fato, de outro tempo, nos permite pensar, antes de tudo, nos preceitos jurídicos e políticos que hoje constituem o Brasil. Falar no Brasil, do ponto de vista do discurso analítico, eurocêntrico, sobre etnias indígenas, conhecê-las, é, assim, uma reprodução da atrocidade. É a subjugação do Outro ao dispositivo do saber e do poder implicado a quem organiza a dinâmica do saber. Deve-se escutar, escutar mesmo no silêncio. Essa sim é certamente uma questão de justiça, de como se deve pensar a Justiça antes do Direito. É também uma questão de ética dentro e fora da política e da economia. Nesse sentido, é fundamental que os/as indígenas falem o que são seus direitos! Uma questão de direito é não apenas a garantia de seus direitos do ponto de vista constitucional, mas também suas compreensões do Direito. Como diz Viveiros de Castros, o Direito de determinar quem são índios e não-índios não pode ser uma questão de Estado ou de direito pensado pelo Estado, ou de estudo étnico. Os próprios povos indígenas, com seus critérios, são os únicos que efetivamente podem determinar quem são. É uma inversão da lógica do Direito, que permite direitos dentro e fora do Estado ${ }^{12}$.

Nesse aspecto, não se pode reduzir os povos indígenas a uma "questão", como se existisse um problema indígena a ser resolvido por Nós outros. Não há questão indígena, e sim violência de um Estado que se funda por meio do massacre e não conhece lógicas distintas que não sejam as de suas próprias determinações. Assim, pois bem, se a lógica do poder soberano é ser guiado por suas próprias determinações. Se suas regulamentações valem como critério de soberania, então que se olhe para suas determinações constitucionais. O que se vê? Não há questão indígena. O que há são indicações sobre o que se deve fazer: em síntese, permitir que os povos indígenas existam, reconhecendo que possuem terras e territorialidades. Os povos indígenas, não podem ser mortos em suas próprias terras. E, muito além disso, todo seu modo de vida deve ser garantido. Esses

12 Ver Eduardo Viveiros de Castros, entrevista, No Brasil, todo mundo é indio, exceto quem não é. https://pib.socioambiental.org/files/file/PIB_institucional/No_Brasil_todo_mundo_é_índio.pdf 
povos devem ter acesso a terras suficientes para preservação de suas culturas e formas de vida. Assim, a tese do Marco Temporal, além de equivocada juridicamente, é de um cinismo oportunista que agride o Estado de direito. Agride de forma frontal a Constituição e as noções elementares de direitos humanos. Reafirmar esses direitos dos indígenas não é um gesto radical, subversivo ou qualquer coisa do gênero, ao contrário, é simplesmente um ato de soberania, é uma ação dentro da Constituição.

\section{Para recomeçar...}

Escutar o que os indígenas pensam do Direito talvez possa nos levar a alguma compreensão efetiva de nós mesmos, para repensar o que é o Direito na perspectiva do Outro ou do Outro do Outro. Um movimento no qual guardaríamos ainda algum sentido para isso que resta da Constituição. Por fim, não concluo esse texto, recomeço-o com Kopenawa e Guajajara. São falas que abrem esse texto. Não são citações e, por isso, estão sem aspas. Essas falas são a abertura para tudo isso que foi escrito até aqui. Momento ambivalente, pois deixo esse texto sem o deixar completamente, saio sem sair, entrego a Outros: para ele, Kopenawa, e para ela, Guajajara.

\section{Kopenawa em a Queda do Céu. ${ }^{13}$}

E, por fim, chegou a minha vez de falar! [...] Eu não sei falar como os brancos! Quando tento imitálos, minhas palavras fogem ou se emaranham na minha boca, mesmo que meu pensamento permaneça reto! Minha língua não seria tão enrolada se eu estivesse falando aos meus, na minha língua! Mas pouco importa, já que vocês me dão ouvidos, vou tentar! Desse modo minhas palavras se fortalecerão e talvez um dia sejam capazes de deixar preocupados os grandes homens dos brancos! [...] Os garimpeiros se tornaram cada vez mais numerosos nas terras altas de nossa floresta, saqueando as nascentes dos rios e destruindo seus habitantes com suas epidemias[...]. No passado, muitos dos nossos morreram por causa das doenças de vocês. Hoje, não quero que nossos filhos e netos morram da fumaça do ouro! Mandem os garimpeiros embora de nossas terras! São seres maléficos, de pensamento obscuro. Não passam de comedores de metal cobertos de epidemia xawara [...] Vocês que me escutam, vocês são para nós estrangeiros que chamamos de napë. Eu sou filho da gente que Omama criou na floresta no primeiro tempo. Eu nasci de seu esperma e de seu sangue! Como meus antepassados, tenho em mim o valor de sua imagem! É por isso que defendo a terra que ele lhes deixou! [...] Vocês são outra gente. Vocês não dão festas reahu. Vocês não sabem fazer dançar os xapiri. Nós somos o pouco de habitantes da floresta sobreviventes das fumaças de epidemia de seus pais e avós. É por isso que quero lhes falar. Hoje, não permaneçam surdos a

${ }^{13}$ (KOPENAWA, 2015, p. 385-387).

Cadernos Cajuína, V. 4, N. 3, 2019, p. 166-185. 
minhas palavras e proíbam os seus de destruir nossa terra e acabar conosco também! Falar da morte de meus maiores me entristece, e a ira de seu luto imediatamente volta ao meu peito [...]. Então, insisto com força: vocês não entendem por que queremos proteger nossa floresta? Perguntam-me, eu responderei! Nossos antepassados foram criados com ela no primeiro tempo. Desde então, os nossos se alimentam de sua caça e de seus frutos. Queremos que nossos filhos lá cresçam rindo. Queremos voltar a ser muitos e continuar a viver como nossos antigos. Não queremos virar brancos! Olhem para mim! Imito a sua fala como um fantasma e me embrulho em roupas para vir lhes falar. Porém, em minha casa, falo em minha língua, caço na floresta e trabalho em minha roça. Bebo yâkeoana e faço dançar meus espíritos. Falo a nossos convidados em diálogos wayamuи e yãimuu! Sou habitante da floresta e não deixarei de sê-lo! Assim é!

\section{Guajajara em resposta a Senadores ruralistas no Senado Federal 12/04/2019}

O setor ruralista que representa a Câmara e o Senado querem a qualquer custo flexibilizar a legislação ambiental para poder explorar os territórios, mas a visão de terra que vocês tem é muito diferente da visão de terra que a gente tem. Não dá para você olhar para nós povos indígenas e pensar que a gente tem o mesmo entendimento de território como o seu que é de exploração, destruição pensando em lucro, pensando em dinheiro. Não é esse o entendimento nosso, para nós o território é sagrado, precisamos dele para existir. Vocês olham para a terra indígena e chamam de improdutiva. Nós chamamos de vida. O mundo inteiro está preocupado com o aquecimento global, discutindo efeitos das mudanças climáticas, pensando formas de reduzir o gás carbônico para garantir que a gente tenha equilíbrio do clima. E aqui no Brasil, é bem mesmo a cara desse governo truculento, de querer o tempo todo aqui, agora, autorizar a entrega desses territórios para exploração, porque não pensa na vida, só pensa em dinheiro, só pensa em lucro. É uma ganância para atender o capitalismo. Nós não! Nós defendemos a vida! Defendemos nossa identidade e nós vamos derramar até a última gota de sangue para defender nossos territórios, para garantir a existência de nossos povos, não vamos entregar isso fácil para essa ganância do agronegócio [...].

\section{REFERÊNCIAS}

CASTROS, Eduardo Viveiros de. O anti-narciso: lugar e função da antropologia no mundo contemporâneo. In. Revista Brasileira de Psicanálise · Volume 44, n. 4, 15-26. 2010.

\footnotetext{
${ }^{14}$ Disponibilizado por Mídia-ninja em https://www.youtube.com/watch?v=qc0ze7cv7dE.
} 
CASTROS, Eduardo Viveiros de in. KOPENAWA, David e ALBERT, Bruce. A queda do Céu, trad. Beatriz Perrone-Moisé. São Paulo, Companhia das Letras, 2015.

DERRIDA, Jacques. Force de loi. Paris, Éditions Galilée, 1994.

Adieu à Emmanuel Lévinas. Paris, Éditions Galilée, 1997.

KOPENAWA, David \& ALBERT, Bruce. A queda do Céu, trad. Beatriz Perrone-Moisé. São Paulo, Companhia das Letras, 2015.

LÉVI-STRAUSS, Claude, Presentation. Chroniques d'une conquête, Ethnies, in Kopenawa David e Bruce Albert, A queda do Céu, trad. Beatriz Perrone-Moisé. São Paulo, Companhia das Letras, 2015.

MIRANDA, Janira Sodré. Macuxi, Etno-História E História Oral: possibilidades metodológicas para a historiografia indígena. Revista Temporis, v.18. n.1. jan./jun. 2018 p. 127-145).

TOCQUEVILLE, Alexis de. De la Démocratie en Amérique. Paris: Institut Coppet, 2012.

SPIVAK, Gayatri Chakravorty. Can the subaltern speak? Basingstoke : Macmillan, 1988. 